earlier diagnosis and treatment. Reports of clinical remission induced by immunosuppression have not taken this into account and future trials may need to be evaluated in this light. ${ }^{26}$ Early detection of metabolic abnormalities would improve the chances for success of intervention, but prediction at a much earlier stage (even before impaired glucose tolerance is found) would offer the best prospect of preserving viable numbers of functioning $\beta$ cells.

We thank the families for their enthusiastic cooperation over many years; Drs J Lister, R Scott, B Thomson, T Westcott, and others for referring patients; and Dr P L Drury for advice. The family study receives continued support from the British Diabetic Association. ACT and KMS were funded by the Medical Research Council. Further generous support has been received from the Leverhulme Trust and Novo Laboratories.

\section{References}

1 Jolly H. Diseases of children. Sth ed. Oxford: Blackwell, 1985:575.

2 Hamilton DV, Mundia SS, Lister J. Mode of presentation of juvenile diabetes. Br Med $\mathcal{J}$ 1976;ii:211-2.

3 Gorsuch AN, Spencer KM, Lister J, et al. The natural history of type I (insulin-dependent) diabetes mellitus: evidence for a long prediabetic period. Lancet 1981 ;i: $1363-5$.

4 Jackson RA, Morris MA, Haynes BF, Eisenbarth GS. Increased circulating Ia-antigen-bearing T cells in type 1 diabetes mellitus. N Engl f Med 1982;306:785-8.

5 Srikanta S, Ganda OP, Jackson RA, et al. Type 1 diabetes mellitus in monozygotic twins: chronic progressive beta cell dysfunction. Ann Intem Med 1983;99:320-6.

6 World Health Organisation. Diabetes mellitus. Report of a WHO study group. WHO Tech Rep Ser 1985; No 727.

7 National Diabetes Data Group. Classification and diagnosis of diabetes mellitus and other categories of glucose intolerance. Diabetes 1979;28:1039-57.

8 Patterson CC, Thorogood M, Smith PG, Heasman MA, Clarke JA, Mann JI. Epidemiology of type 1 (insulin-dependent) diabetes in Scotland 1968-1976: evidence of increasing incidence. Diaberologia 1983;24:238-43.

9 Sharkey TP, Troup P, Miller R, Van Kirk HC, Freeman R, Williams HH. Diabetes detection drive in Dayton, Ohio. JAMA 1950;144:914-9.

10 Lind T, Anderson J. Does random blood glucose sampling outdate testing for glycosuria in the detection of diabetes during pregnancy? Br Med $\mathcal{J}$ 1984;289:1569-71.

11 Spencer KM, Tarn A, Dean BM, Lister J, Bottazzo GF. Fluctuating islet-cell autoimmunity in unaffected relatives of patients with insulin-dependent diabetes. Lancet 1984;i:764-6.

12 Johansen K. Mild carbohydrate intolerance developing into classic juvenile diabetes. Acta Med Scand 1981;189:337-9.

13 Hales CN. Plasma-levels of glucose, non-esterified fatty acid, glycerol and insulin four years before the onset of diabetic ketoacidosis. Lancet 1967;ii:389-90.

14 Fajans SS, Floyd JC, Tattersall RB, Williamson JR, Pek S, Taylor CI. The various faces of diabetes in the young. Changing concepts. Arch Intern Med 1976;136:194-202.

15 Rosenbloom AL, Hunt SS, Rosenbloom EK, MacLaren NK. Ten-year prognosis of impaired glucose tolerance in siblings of patients with insulin-dependent diabetes. Diabetes 1982;31: 385-7.

16 Orchard TJ, Rosenbloom AL. The development of insulin-dependent diabetes mellitus among relatives. Diabeles Care 1985;8(suppl 1):45-50.

17 Hoskins PJ, Leslie RDG, Pyke DA. Height at diagnosis of diabetes in children: a study in identical twins. BrMed I 1985;290:278-80.

18 Lister J. The clinical spectrum of juvenile diabetes. Lancet 1966;ii:386-8.

19 Wilson RM, Van der Minne P, Deverill I, et al. Insulin dependence: problems with the ilson RM, Van der Minne P, Deverill I, et al. Insulin dependence:
classification of 100 consecutive patients. Diaberic Medicine 1985;2:167-72.

20 Ludvigsson J, Samuelsson U, Beauforts C, et al. HLA-DR3 is associated with a more slowly progressive form of type 1 (insulin-dependent) diabetes. Diabetologia 1986;29:207-10.

21 Bottazzo GF, Cudworth AG, Moul DJ, Doniach D, Festenstein H. Evidence for a primary autoimmune type of diabetes mellitus. $\mathrm{Br}$ Med $\mathcal{O}$ 1978;ii:1253-5.

22 Banatvala JE, Schernthaner G, Schober E, et al. Coxsackie B, mumps, rubella, and cytomegalo virus specific IgM responses in patients with juvenile-onset insulin-dependent diabetes mellitus in Britain, Austria, and Australia. Lancet 1985;i:1409-12.

23 Bottazzo GF. Death of a beta cell: homicide or suicide? Diaberic Medicine 1986;3:119-30.

24 Gamble DR, Taylor KW. Seasonal incidence of diabetes mellitus. Br Med J 1969;iii:631-3.

25 White P. Natural course and prognosis of juvenile diabetes. Diabetes 1956;5:445-50.

26 Stiller CR, Dupre J, Gent $M$, et al. Effects of cyclosporine immunosuppression in insulindependent diabetes mellitus of recent onset. Science 1984;223:1362-7.

(Accepted 28 November 1986)

\title{
Comprehensive care of patients with head injuries
}

\author{
GORDON BROCKLEHURST，MICHAEL GOODING，GARY JAMES
}

\begin{abstract}
The comprehensive head injury service run by the neurosurgeons at the Hull Royal Infirmary for the surrounding population of one million was analysed. The analysis showed that all patients with either a fractured skull or a lowered level of consciousness should be admitted to a district general hospital because the associated risk of their having a major head injury is over $20 \%$. Those patients with both a fractured skull and a lowered level of consciousness have a $60 \%$ likelihood of a major head injury and should be transferred immediately to the neurosurgical unit. Patients with compound or complicated fractures of the skull and those without fractured skulls but with neurological impairment persisting for four hours or more, should also be transferred to the neurosurgical unit.

If these guidelines are followed about 200 patients/million population will be referred to the neurosurgical centre. Patients
\end{abstract}

Neurosurgical Department, Royal Infirmary, Hull HU3 2JZ

GORDON BROCKLEHURST, MD, FRCS, consultant neurosurgeon

MICHAEL GOODING, MD, FRCS, consultant neurosurgeon

GARY JAMES, BSC, RGN, research assistant

Correspondence to: Mr Brocklehurst. with a minor head injury and none of the clinical risk factors may safely be sent home. This should reduce the rate of admissions to hospital for head injuries by $60 \%$.

\section{Introduction}

When the Royal Infirmary in Hull was opened in 1967 it was decided that all patients who required admission to hospital after a head injury would come directly under the care of the neurosurgeons. In addition to patients with obvious major head injuries, those with minor head injuries were admitted if they had the following signs: loss of consciousness (however brief); headache; and vomiting and unsteadiness, particularly in children. Skull radiographs were obtained for all patients with any kind of head injury, and radiological proof of a fractured skull was a further criterion for admission.

The neurosurgeons at this hospital have thus provided a clinical service for all patients with minor or major head injuries for the population on the north bank of the Humber (about 500000). During this time the neurosurgeons have also accepted all patients with head injuries referred to them from the two district general hospitals south of the Humber and other smaller hospitals around Hull. The total population served by these referring hospitals is also about 500000 (see figure). This combined service is part of a neurosurgical practice that has grown in recent years (see table I) with satisfactory results.

In the past two years the identification of several factors correlated with the risks of intracranial haematoma in patients with 
head injuries, and the obvious benefits of combining the siting of neurosurgical skill with the efficient use of computed tomography have led to suggestions that more patients should be referred early to neurosurgical units and that many patients with minor head injuries need not be admitted to hospital at all. ${ }^{2}$ An admission policy for

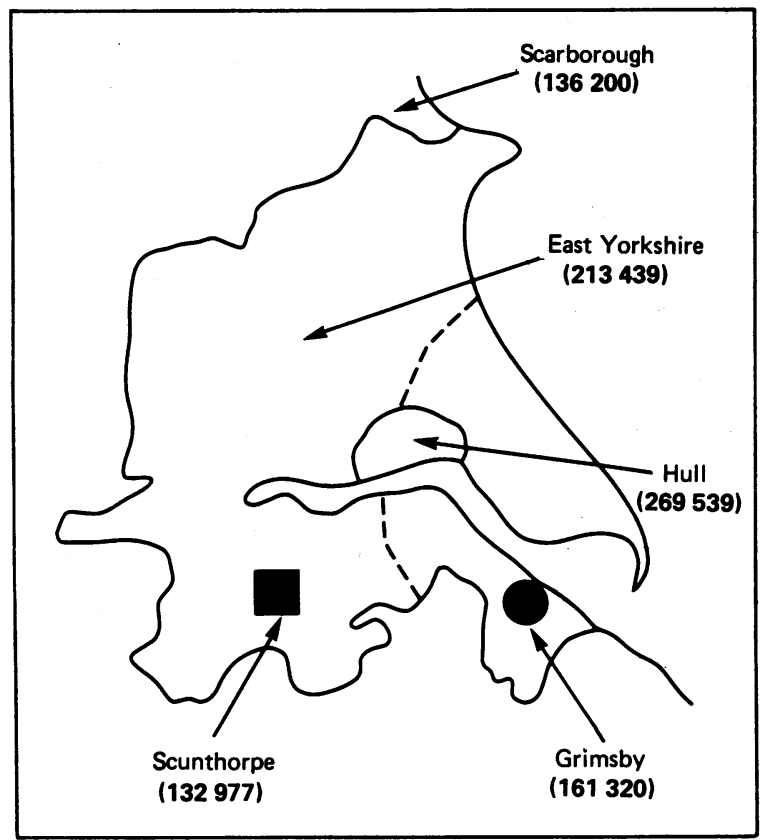

District health authorities and their respective populations served by the head injury service at the Hull Royal Infirmary. (Figures from 1981 census.)

patients with head injuries based on these observations, as suggested recently by a group of neurosurgeons, ${ }^{34}$ would probably increase efficiency and improve allocation of resources. ${ }^{25}$ Before putting this policy into practice in Humberside, however, we analysed the current practice to confirm the risk factors and predict the probable effect of any changes in policy.

\section{Patients and methods}

A prospective study of all patients admitted to this hospital with head injuries between 1 July and 31 December 1984 was undertaken to obtain detailed information about particular clinical features, diagnosis, and duration of stay. The research assistant saw all of the patients with head injuries each morning with the medical staff. The clinical features recorded included the level of consciousness when the patient was seen in the accident and emergency department (as judged by the Glasgow coma scale ${ }^{6}$ ), the absence or presence of fractured skull (all patients with head injuries having undergone skull radiography), and any other major injuries. The diagnosis was recorded from the classification used in the neurosurgical department (see table II); the details of patients with head injuries for the years 1982, 1983 , and 1984 were obtained from the same source.

\section{Results}

The figure shows the area and populations served by the neurosurgeons at this hospital for direct admissions and referrals, respectively, and table I shows the number of patients with minor and major head injuries admitted to the neurosurgical department over the past seven years. Table II shows the diagnostic groups for the years 1982, 1983, and 1984. Tables III to VI show the relation of level of consciousness and the absence or presence of a fractured skull to the diagnosis of minor and major head injury and to the duration of stay in hospital, respectively.

Using these observations we calculated risk factors as percentages by taking the number of patients with major head injuries with the particular
TABLE I-Number of patients seen in neurosurgical department 1977-84

\begin{tabular}{|c|c|c|c|c|c|c|c|c|}
\hline & 1977 & 1978 & 1979 & 1980 & 1981 & 1982 & 1983 & 198 \\
\hline $\begin{array}{l}\text { No of patients seen } \\
\text { No of patients with } \\
\text { minor head injuries }\end{array}$ & $\begin{array}{l}1507 \\
1008\end{array}$ & $\begin{array}{l}1579 \\
1007\end{array}$ & $\begin{array}{l}1786 \\
1114\end{array}$ & $\begin{array}{l}1738 \\
1022\end{array}$ & $\begin{array}{r}1690 \\
862\end{array}$ & $\begin{array}{r}1707 \\
935\end{array}$ & $\begin{array}{l}1879 \\
1092\end{array}$ & 2042 \\
\hline $\begin{array}{l}\text { No of patients with } \\
\text { major head (and } \\
\text { spinal) injuries }\end{array}$ & 116 & 108 & 128 & 143 & 164 & 140 & 129 & 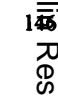 \\
\hline
\end{tabular}

TABLE II-Patients seen with head injuries 1982-4. Figures in parentheses are patiexints referred from other hospitals

\begin{tabular}{lccr}
\hline Type of injury & 1982 & 1983 & 1984 \\
\hline Minor head injury & 935 & 1092 & 1161 \\
Major head injury & $119(35)$ & $99(35)$ & $122(30)$ \\
Cerebral contusion & 86 & 62 & 76 \\
Open fracture of skull & 7 & 7 & 16 \\
Dural tears & 2 & 7 & 5 \\
Extradural haematoma & 6 & 6 & 9 \\
Subdural haematoma & 15 & 13 & 6 \\
Intracerebral haematoma & 3 & 4 & \\
\hline
\end{tabular}

TABLE III-Relation between level of consciousness and severity of head injugy Values are numbers $(\%)$ of patients

\begin{tabular}{|c|c|c|c|}
\hline & \multicolumn{3}{|c|}{ Severity of head injury } \\
\hline & Major & Minor & Total T \\
\hline $\begin{array}{l}\text { Lowered level of consciousness } \\
\text { Alert } \\
\text { Totals }\end{array}$ & $\begin{array}{l}44(28) \\
9(2) \\
53\end{array}$ & $\begin{array}{l}111(71) \\
588(99) \\
699\end{array}$ & $\begin{array}{l}155 \frac{0}{\frac{c}{2}} \\
597 \stackrel{2}{\frac{2}{2}}\end{array}$ \\
\hline
\end{tabular}

clinical feature $\times 100$ /all patients with head injuries with the same cliniea feature. For the 155 patients who were suffering from a lowered levelof consciousness when seen in the accident and emergency department this $28 \%$ and for the 111 with a fractured skull $32 \%$; for the 41 patients who had a lowered level of consciousness and a fractured skull the factor wh $64 \%$. The same calculation for either of these clinical features gives he probability that a patient with a fractured skull or a lowered level -9 consciousness has a major head injury as $22 \%$, and if these two criteria hoj been used all patients with major head injuries would have been admitted:-

\section{Discussion}

Knowledge of the probability that a patient might have more thin a minor head injury, or by our diagnostic criteria one of the various forms of major head injury, is more useful to the doctor assessigg these patients in the accident and emergency department than knowledge of the risk of an intracranial haematoma as calculated from the widespread analysis of head injuries in Scotland. ${ }^{1}$ Om analysis shows that a fractured skull or a lowered level of consciousness is associated with a greater than one in five chance ofa head injury that is more than minor, and these patients should obviously be admitted to the local hospital. It also confirms the patients with the combination of a fractured skull and a lowered level of consciousness have an almost two in three chance of havinga major head injury and should therefore immediately be transferred to a neurosurgical unit. The findings support and supplement the observations from Scotland'; they also endorse two of the moin points in the recently published guidelines for the initial managment of patients with head injuries. ${ }^{34}$ The relation between the same clinical features and whether or not the patient was kept in hospifal for 24 hours reflects the practical aspects of running a head injugy service (tables IV and V). Of the patients with major head injuries, 11 died, 34 remained in hospital for 48 hours, and three were on hospital for $24-48$ hours. Of the five patients with major heagd 
injuries who stayed in hospital for less than 24 hours, two discharged themselves, two had been referred from another hospital, which they returned to after assessment, and one was a patient with a compound fractured skull who underwent surgical repair on admission and was then transferred for orthopaedic management.

TABLE IV-Relation between fracture of skull and severity of head injury. Values are numbers $(\%)$ of patients

\begin{tabular}{llcc}
\hline & \multicolumn{3}{c}{ Severity of head injury } \\
\cline { 2 - 4 } & \multicolumn{1}{c}{ Major } & Minor & Total \\
\hline Fractured skull & $36(32)$ & $75(68)$ & 111 \\
No fracture & $17(3)$ & $624(97)$ & 641 \\
Total & 53 & 699 & 752 \\
\hline
\end{tabular}

TABLE V-Relation between level of consciousness and duration of stay in hospital. Values are numbers (\%) of patients

\begin{tabular}{lccc}
\hline & \multicolumn{3}{c}{ Duration of stay } \\
\cline { 2 - 4 } & $\leqslant 24 \mathrm{~h}$ & $>24 \mathrm{~h}$ & Total \\
\hline Lowered level of consciousness & $76(49)$ & $79(51)$ & 155 \\
Alert & $504(84)$ & $93(16)$ & 597 \\
Total & 580 & 172 & 752 \\
\hline
\end{tabular}

TABLE VI-Relation between fracture of skull and duration of stay in hospital. Values are numbers $(\%)$ of patients

\begin{tabular}{lrrr}
\hline & \multicolumn{3}{c}{ Duration of stay } \\
\cline { 2 - 4 } & $\leqslant 24 \mathrm{~h}$ & $>24 \mathrm{~h}$ & Total \\
\hline Fractured skull & $52(47)$ & $59(53)$ & 111 \\
No fracture & $528(82)$ & $113(18)$ & 641 \\
Total & 580 & 172 & 752 \\
\hline
\end{tabular}

When all those with a fractured skull or a lowered level of consciousness are removed from the no risk group the number of patients requiring admission is reduced from 752 to 278 (a reduction of $63 \%$ ), and with the use of these criteria no patients with a diagnosis of a major head injury would have been discharged. In practice, 66 of the patients with no risk of major head injury were detained for more than 24 hours, and of these, 39 remained in hospital because of non-neurosurgical problems such as orthopaedic, faciomaxillary, or general surgical injuries. The remaining 27 patients stayed in hospital because of persistent symptoms such as nausea, dizziness, headaches, and vomiting. These 27 represent $4 \%$ of all the patients seen and could constitute the small proportion of the no risk group that might reattend hospital having been sent home initially.
Tables I and II show that the number of patients admitted with major head injuries rose in 1979 to reach its present level by 1980 , indicating the effect of computed tomography on the diagnosis of head injuries. ${ }^{7}$ The absence of a further rise in 1982, when the Humber Bridge was opened, suggests that patients were already being brought to the hospital by helicopter or a long ambulance transferral. Table II indicates, however, that for the past three years analysed only about a third of the patients with major head injuries came from outside the Hull Royal Infirmary. If referrals were encouraged according to the criteria set out above the number of patients with major head injuries for the population of a million might increase to 200 a year. Among these, the number of patients admitted with surgically treatable intracranial haematomas each year might rise above the remarkably constant 25 but is unlikely to reach the 36 or more per million suggested by the Clydeside and Merseyside studies. ${ }^{18}$

This study has confirmed the value of obtaining skull radiographs of good diagnostic quality in all patients with a history or signs of a definite impact to the head, or both, and of treating a fractured skull as a criterion for admission to hospital and the complications of a fractured skull as criteria for neurosurgical referral. These findings also support the recently produced guidelines. ${ }^{34}$

The allocation of 28 beds for neurosurgical patients, with an average of four or five used for patients with major head injuries (those with minor head injuries being admitted to empty beds elsewhere in the hospital), was therefore changed to 36 , allowing some eight to 10 beds for patients with head injuries. This number is larger than that suggested by other units, where the emphasis has been on referral for surgery rather than comprehensive care. ${ }^{5}$ Our experience indicates, however, that eight to 10 beds are needed for the neurosurgical care of all patients with a major head injury from a population of one million.

The admission of the lower risk and no risk patients to a short stay ward in the accident and emergency department has freed neurosurgical resources for the care of the high risk group. Children with head injuries and high or low risk factors are admitted to the paediatric ward, as are many other children with no risk factors other than difficulty in clinical neurological assessment, particularly if they are unlikely to be observed accurately at home. When patients with minor head injuries and no risk factors are sent home they are provided with printed instructions on care and observation.

\section{References}

1 Mendelow AD, Teasdale G, Jennett B, Bryden J, Hessett C, Murray G. Risks of intracranial haematoma in head injured adults. BrMed f 1983:287:1173-6.

2 Mendelow AD, Campbell DA, Jeffrey RR, et al. Admission after mild head injury: benefits and costs. Br.Med f 1982:285:1530-2.

3 Lewis AF. The management of acute head injury. London: HMSO, 1983. (DHSS Harrogate Seminar Report No 8.)

4 Suggestions from a group of neurosurgeons. Guidelines for initial management after head injury in adults. Br Med J 1984;288:983-5.

5 Bryden JS, Jennett B. Neurosurgical resources and transfer policies for head injuries. Br Med $\mathcal{F}$ 1983;286:1791-3.

6 Teasdale G, Jennett B. Assessment of coma and impaired consciousness. Lancet 1974;ii:81-4.

7 Ambrose J, Gooding MR, Uttley D. EMI scan in the management of head injuries. Lancet 1976;i:847-8.

8 Jeffreys RV, Azzam NI. Experiences with head injuries in a regional neurosurgical unit. Br $\mathcal{J}$ Surg 1979;66:562-4.

(Accepted 11 November 1986) 